\title{
Peningkatan Prestasi Belajar Mata Pelajaran IPA melalui Model Pembelajaran Bamboo Dancing
}

\author{
Subani \\ SDN I Watuagung Trenggalek \\ Email: sdn1watuagung@gmail.com
}

\begin{tabular}{l}
\hline Tersedia Online di \\
\hline http://www.jurnal.unublitar.ac.id/ \\
index.php/briliant \\
\hline Sejarah Artikel \\
\hline Diterima pada 2 April 2017 \\
Disetuji pada 6 April 2017 \\
Dipublikasikan pada 1 Mei 2017 \\
Hal. 190-196 \\
\hline Kata Kunci: \\
\hline prestasi belajar, ipa, bamboo \\
dancing
\end{tabular}

\begin{abstract}
Abstrak: Tujuan dari penelitian ini adalah untuk mengetahui bagaimanakah peningkatan prestasi belajar mata pelajaran IPA melalui model pembelajaran bamboo dancing bagi siswa kelas VI di SDN 1 Watuagung Kecamatan Watulimo Kabupaten Trenggalek. Subjek yang diteliti adalah siswa kelas VI semester I tahun pelajaran 2016/2017 di SDN 1 Watuagung Kecamatan Watulimo kabupaten Trenggalek yang berjumlah 10 siswa. Data dianalisis secara statistik, dan menghasilkan kesimpulan : "Terjadi peningkatan prestasi belajar mata pelajaran IPA melalui model pembelajaran bamboo dancing bagi siswa kelas VI di SDN 1 Watuagung Kecamatan Watulimo Kabupaten Trenggalek pada semester I tahun pelajaran 2016/2017.
\end{abstract}

Setiap hari anak selalu berinteraksi dengan alam dan lingkungannya. Oleh karena itu siswa sudah mempunyai pengalaman tentang banyak hal, yang berkaitan dengan alam, baik yang biotik maupun non biotik. Pengetahuan anak tentang alam sekitar, hendaknya tidak disia-siakan. Sebaliknya harus dapat dipergunakan untuk berbagai macam kepentingan, termasuk di dalamnya dimanfaatkan dalam proses pembelajaran di kelas. Pengalaman anak perlu digali dan dikembangkan sehingga pembelajaran dapat benar-benar bermakna.

Kelas adalah milik bersama, bukan hanya milik guru. Oleh karena itu proses pembelajaran juga jangan didominasi oleh guru semata. Dalam hal ini seharusnya anak lebih berperan. Oleh karena itu guru harus pandai-pandai memilih metode mengajar yang dapat benar-benar melibatkan anak dan memberikan keberhasilan anak dalam kegiatan belajar.

Sudah menjadi adat dan kebiasaan, bahwa dalam melaksanakan proses pembelajaran, guru lebih senang berceramah dan menjelaskan materi yang sedang dikaji, dari pada mencoba menjajaki sejauh mana anak mempunyai pengetahuan dan pengamalan pada materi tersebut. Guru merupakan single actor dalam proses pembelajaran, sementara siswa menjadi pendenga dan penonton yang setia.

Penelitian ini meneliti subjek penelitian yang berjumlah 10 siswa (dalam satu kelas). Tentunya hal tersebut merupakan jumlah yang sangat kecil. Dengan jumlah tersebut, tentunya kita dapat membayangkan alangkah susahnya mencapai keberhasilan, karena guru dapat memberikan perhatian yang maksimal. Tentunya siswa dapat mencapai nilai yang sangat bagus. Tetapi pada kenyataan yang ditemui, nilai yang dapat dicapai oleh siswa belumlah maksimal.

Pada tahap pra siklus, memasang KKM 70. Data yang berhasil dari tahap pra siklus menunjukkan siswa tuntas sebanyak 6 siswa. Masih ada 4 siswa yang tertinggal dan tidak tuntas. Berarti tingkat ketuntasan belajar hanya mencapai $60 \%$. Sungguh hal tersebut dapat dikatakan guru tidak berhasil dalam 
pembelajaran. Jumlah siswa yang hanya 10 tersebut, mestinya dapat mencapai tingkat ketuntasan belajar yang lebih tinggi.

Pada tahap pra siklus, guru memberikan pembelajaran dengan menerapkan metode ceramah. Karena jumlah siswanya hanya sedikit, guru menghemat tenaga dengan duduk di depan kelas. Suaranya cukup keras, dan sesekali menulis beberapa hal yang dianggap penting di papan tulis. Komunikasi banyak berlangsung satu arah saja. Siswa terlihat pasif, dan tidak banyak dilibatkan dalam kegiatan pembelajaran.

Siswa tuntas pada pra siklus sebayak 6 siswa (60\%). Tentunya angka tersebut merupakan angka yang cukup memprihatinkan, dan masih diperjuangkan untuk peningkatannya.

Melihat tingkat ketuntasan belajar di atas, tentunya wajar dan bahkan harus menjadi perenungan bagi guru, untuk mengadakan inovasi khususnya dalam hal pembelajaran. Guru mencoba mengadakan refleksi diri, dan menemukan beberapa hal yang sekiranya dapat dijadikan bahan pemikiran untuk melaksanakan pembelajaran berikutnya. Hal yang dimaksud adalah sebagai berikut: (1) posisi guru saat mengajar kurang bervariasi, (2) guru kurang mengaktifkan siswa, (3) guru tidak menggunakan media.

Dari permasalahan tersebut maka diperlukan suatu solusi. Solusi yang dapat diterapkan untuk mengatasi permasalahan tersebut adalah dengan menerapkan pembelajaran ipa berbasis model pembelajaran bamboo dancing.

\section{METODE}

Penelitian ini merupakan Penelitian Tindakan kelas (PTK) Untuk memahami apa yang dimaksud dengan Penelitian Tindakan Kelas (PTK) berikut adalah kutipan yang diambil dari pendapat ahli. Penelitian Tindakan Kelas adalah: "Suatu pencermatan terhadap kegiatan belajar berupa suatu tindakan, yang sengaja dimunculkan dan terjadi dalam suatu kelas secara bersama" (Arikunto, 2011:3).

Pendapat yang lain menyatakan bahwa Penelitian Tindakan kelas adalah: Suatu bentuk penelitian yang bersifat reflektif dengan melakukan tindakantindakan tertentu untuk memperbaiki dan meningkatkan praktik pembelajaran di kelas secara lebih berkualitas sehingga siswa dapat memperoleh hasil belajar yang lebih baik (Mohammad Asori, 2011:6).

Sesuai pendapat di atas, yang dimaksud PTK adalah penelitian tindaka, dimana peneliti merupakan pelaku langsung dari kegiatan penelitian. Adanya tindakan dimaksudkan untuk memperbaiki proses pembelajaran, sehingga pembelajaran menjadi lebh baik.

Penelitian Tindakan Kelas (PTK) ini direncanakan selesai dalam waktu sekitar 3 bulan, yakni bulan Agustus dan Oktober 2016, mulai dari perencanaan sampai selesainya penyusunan laporan.

Pelaksanaan penelitian tahap pra siklus dilaksanakan pada Minggu ke 1 bulan Agustus 2016, Siklus I dilaksanakan pada minggu ke 2 bulan Agustus 2016, dan siklus II dilaksanakan pada minggu ke 3 bulan Agustus 2016. Selanjutnya, sampai akhir Oktober 2016 dipergunakan untuk penyusunan laporan

Sesuai dengan tahapan dalam PTK, maka penelitian ini juga melaksanakan 4 tahapan dalam masing-masing siklus, yakni tahap perencanaan, tehap pelaksanaan tindakan, tahap pengamatan, dan tahap pelaporan.

191 BRILIANT: Jurnal Riset dan Konseptual

Volume 2 Nomor 2, Mei 2017 
Pada tahap perencanaan siklus I dilaksanakan kegiatan sebagai berikut: (1) menyusun Rencana Pelaksanaan Pembelajaran (RPP), (2) enyusun LKS sesuai dengan materi, (3) menyiapkan sumber dan media pembelajaran, (4) menyusun format evaluasi/soal tes akhir, (5) menyusun format observasi pembelajaran

Tahap pelaksanaan tindakan merupakan tahap dimana peneliti melaksanakan proses pembelajaran di kelas. Tentunya tahap ini dilaksanakan sesuai dengan perencanaan.

Mengingat pada penelitian ini model pembelajaran yang dipergunakan adalah bamboo dancing (tari Bambu), maka pelaksanaan tidakan dilakukan dengan langkah (1) separuh kelas (atau seperempat jika jumlah siswa telalu banyak) berdiri berjajar. Jika ada cukup ruang, mereka bisa berjajar didepan kelas, (2) kemungkinan lain adalah siswa berjajar di sela-sela deretan bangku. Cara yang kedua ini akan memudahkan pembentukan kelompok karena diperlukan waktu yang relatif singkat, (3) separuh kelas lainnya berjajar dan menghadap jajaran yang pertama, (4) dua siswa yang berpasangan dari kedua jajaran berbagi informasi, (5) kemudian, satu atau dua siswa yang berdiri di ujung salah satu jajaran pindah keujung lainnya di jajarannya. Jajaran ini kemudian bergeser. Dengan cara ini, masing-masing siswa mendapatkan pasangan yang baru untuk berbagi informasi .

Pergeseran bisa dilakukan terus sesuai dengan kebutuhan (1) tari bambu kelompok, (2) satu kelompok berdiri di satu jajaran berhadapan dengan kelompok lain, (3) kelompok bergeser seperti prosedur tari bambu individu di atas, kemudian mereka pun saling berbagi informasi

Pengamatan dilakukan dengan menggunakan pedoman yang berwujud lebar observasi siswa. Dalam lembar observasi tersebut tercatat seberapa banyak siswa yang aktif dan siswa yang tidak aktif. Pengamatan dilakukan pada setiap pembelajaran berlangsung, sehingga dapat dipergunakan untuk mengetahui sejauh mana peningkatan keaktifan siswa pada masing-masing siklus.

Tahap akhir dari penelitian tindakan kelas adalah melakukan refleksi. Hal-hal yang dilakukan pada tahap ini adalah: (a) menganalisis hasil pengamatan, (b) menganalisis hasil tes akhir siswa, (c) mencari solusi dari kekurangan atau kesalahan yang terjadi dari pembelajaran yang sudah berlamgsung.

\section{Subjek Penelitian}

Penelitian ini mengambil subjek penelitian siswa kelas VI SDN 1 Watuagung Kecamatan Watulimo Kabupaten Trenggalek semester I tahun pelajaran 2016/2017 yang berjumlah 10 siswa, terdiri dari 5 siswa laki-laki dan 5 siswa perempuan. Penelitian ini mengambil tempat di SDN 1 Watuagung Kecamatan Watulimo Kabupaten Treggalek Propinsi Jawa Timur. Alasan peneliti mengambil subjek penelitian tersebut, karena penelitin adalah guru yang setiap hari mengajar subjek penelitian. Dengan demikian telah ada ikatan batin yang kuat antara peneliti dengan siswa. Selain itu siswa tidak merasa jika sedang diteliti.

\section{Instrumen Penelitian}

Penelitian tindakan kelas ini menggunakan instrumen yang berwujud lembar pengamatan/observasi dan lembar soal tes akhir. Soal test yang dipergunakan sebanyak 10 soal pilihan ganda. Masing-masing soal dijawab benar 
diberi skor 1, sehingga skor maksimal yang dapat diperoleh siswa adalah 10 . Lembar observasi yang dipergunakan pada siklus I dan siklus II sama, sehingga dapat dipergunakan untuk melihat kemajuan pada aspek yang sama pula.

\section{Teknik Pengumpulan Data}

Pengumpulan data dilakukan dengan menggunakan teknik tes dan non tes. Teknik tes dipergunakan untuk menjaring data tentang prestasin belajar siswa yang diperoleh dari nilai tes akhir, sedangkan non tes dipergunakan untuk menjaring data tentang keaktiufan siswa.

\section{Teknik Analisis Data}

Data dianalisis menggunakan metode analisis data statistik. Adapun tahapan analisisnya adalah sebagai berikut: (1) menyusun tabel penilaian, (2) menghitung skor setiap individu dengan rumus:

$$
\mathrm{NA}=\frac{\text { SkorPerolehan }}{\text { SkorMaksimal }} \times 100
$$

Membuat grafik sebaran nilai dan menghitung persentase peningkatan hasil belajar, dengan rumus:

$$
\begin{aligned}
& \mathrm{NP}=(\mathrm{Rs}-\mathrm{Rd}) \times 100 \% \\
& \text { Keterangan: } \\
& \mathrm{NP}=\text { prosentase kenaikan } \\
& \mathrm{S}=\text { jumlah skor yang diperoleh siswa } \\
& \mathrm{Rd}=\text { Skor rata-rata siklus sebelumnya }
\end{aligned}
$$

\section{HASIL}

\section{Pra Tindakan}

Pada tahap pra siklus ini guru telah menyiapkan perencanaan pembelajaran, mulai dari penyusunan silabus sampai dengan penilaian. Perencanaan pembelajaran pra siklus dapat disampaikan sebagai berikut: (1) menyiapkan silabus, (2) menyiapkan RPP, (3) menyiapkan LKS, (4) menyiapkan instrument penilaian yaitu lembar test uraian, (5) menyiapkan instrument penilaian yaitu lembar observasi

Pada tahap ini, guru melakukan tindakan pembelajaran. Hasil dari test akhir pembelajaran menunjukkan bahwa, 6 siswa dari 10 siswa (60\%) dapat mencapai ketuntasan. Sedangkan jumlah siswa yang belum tuntas mencapai 4 siswa (40\%), yakni yang belum mampu mencapai nilai 70 ke atas (sesuai dengan KKM yang ditetapkan).

Jika dilihat dari kategorinya, dapat disampaikan sebagai berikut (1) siswa yang mencapai kategori istimewa sebanyak 1 siswa (10\%), (2) siswa yang mencapai kategori sangat baik sebanyak 1 siswa (10\%), (3) siswa yang mencapai kategori baik sebanyak 3 siswa (30\%), (4) siswa yang mencapai kategori cukup sebanyak 1 siswa (10\%), (5) siswa yang mencapai kategori kurang sebanyak 4 siswa (40\%).

Dengan demikian, maka modus berada pada nilai kurang sebanyak 4 siswa (40\%), tingkat keaktifan siswa pada tahap pra siklus mencapai 5 siswa 
(50\%) dan siswa yang passif sebanyak 5 siswa (50\%), dan nilai rata-rata kelas sebesar 72 .

Refleksi dari pelaksanaan tahap pra siklus dinyatakan posisi guru saat mengajar kurang bervariasi, guru kurang mengaktifkan siswa, guru tidak menggunakan media.

\section{Siklus I}

Siklus I yang akan dilaksanakan merupakan perbaikan dari tahap pra siklus. Pada tahap ini diterapkan model pembelajaran Bam boo Dancing (tari bambu). Materi pada tahap siklus I adalah : "Menyebutkan ciri-ciri khusus yang dimiliki tumbuhan tertentu (kaktus, kantong semar, raflesia, teratai)." KKM yang ditetapkan adalah 70 .

Tahap perencanaan sebagai tahap awal dala penelitian siklus I meliputi kegiatan (1) menyiapkan silabus pembelajaran siklus I, (2) mengembangkan skenario pembelajaran siklus I, (3) menyiapkan sumber dan media pembelajaran siklus I, (4) menyusun LKS siklus I, (5) menyusun instrument soal test siklus I, dan (6) menyusun format observasi pembelajaran siklus I.

Tahap tindakan dilaksanakan dengan menerapkan langkah-langkah dalam model pembelajaran Bamboo Dancing, sebagai berikut (1) guru menyampaikan tujuan pembelajaran, (2) guru membentuk kelas menjadi dua kelompok, (3) separuh kelas (kelompok I) berdiri berjajar, (4) separuh kelas lainnya berjajar dan menghadap jajaran yang pertama, (5) dua siswa yang berpasangan dari kedua jajaran berbagi informasi tentang ciri-ciri khusus yang dimiliki tumbuhan, (6) kemudian, satu atau dua siswa yang berdiri di ujung salah satu jajaran pindah keujung lainnya di jajarannya, (7) jajaran ini kemudian bergeser, sehingga masing-masing siswa mendapatkan pasangan yang baru untuk berbagi informasi . Pergeseran bisa dilakukan terus sesuai dengan kebutuhan, (8) guru memberikan pemantapan materi, (9) siswa membaca kesimpula(10) siswa mengerjakan test akhir.

Pengamatan difokuskan pada saat kegiatan inti pembelajaran berlangsung, yakni pada saat siswa belajar dengan menerapkan model pembelajaran Bamboo Dancing .

Pengamatan dengan menggunakan lembar observasi yang berisi tentang keaktifan siswa menunjukkan 5 siswa aktif (50\%) dan 5 siswa pasif (50\%). Tingkat keaktifan siswa menurun dibandingkan dengan tahap pra siklus. Hal ini dimungkinkan karena siswa belaum mengenal model pembelajaran ini, sehingga merasa ragu-ragu untuk berpartisipasi

\section{Siklus II}

Siklus II yang akan dilaksanakan merupakan perbaikan dari tahap siklus I. Pada tahap ini diterapkan model pembelajaran Bamboo Dancing (tari bambu). Materi pada tahap siklus II adalah : "Menjelaskan fungsi dari ciri khusus yang dimiliki tumbuhan tertentu (kaktus, kantong semar, raflesia, teratai)". KKM yang ditetapkan adalah 70 .

Tahap perencanaan sebagai tahap awal dala penelitian siklus I meliputi kegiatan sebagai berikut menyiapkan silabus pembelajaran siklus II, mengembangkan skenario pembelajaran siklus II, menyiapkan sumber dan media 
pembelajaran siklus II, menyusun LKS siklus II, menyusun instrument soal tes siklus II, menyusun format observasi pembelajaran siklus II.

Tahap tindakan dilaksanakan dengan menerapkan langkah-langkah dalam model pembelajaran Bamboo Dancing, sebagai berikut guru menyampaikan tujuan pembelajaran, guru membentuk kelas menjadi dua kelompok, separuh kelas (kelompok I) berdiri berjajar, separuh kelas lainnya berjajar dan menghadap jajaran yang pertama, dan dua siswa yang berpasangan dari kedua jajaran berbagi informasi tentang fungsi ciri-ciri khusus yang dimiliki tumbuhan tertentu,

Kemudian, satu atau dua siswa yang berdiri di ujung salah satu jajaran pindah keujung lainnya di jajarannya. Jajaran ini kemudian bergeser, sehingga masing-masing siswa mendapatkan pasangan yang baru untuk berbagi informasi . Pergeseran bisa dilakukan terus sesuai dengan kebutuhan. Guru memberikan pemantapan materi. Siswa membaca kesimpulan. Siswa mengerjakan test akhir.

Pengamatan difokuskan pada saat kegiatan inti pembelajaran berlangsung, yakni pada saat siswa belajar dengan menerapkan model pembelajaran Bamboo Dancing .

Pengamatan dengan menggunakan lembar observasi yang berisi tentang keaktifan siswa menunjukkan 9 siswa aktif (90\%) dan 1 siswa pasif (10\%). Tingkat keaktifan siswa meningkat dibandingkan dengan tahap siklus I. Hal ini dimungkinkan karena sudah mengenal model pembelajaran ini.

\section{PEMBAHASAN}

\section{Siklus I}

Hasil menunjukkan bahwa 8 siswa dari 10 siswa (80\%) dapat mencapai ketuntasan. Sedangkan jumlah siswa yang belum tuntas mencapai 2 siswa (20\%), yakni yang belum mampu mencapai nilai 70 ke atas (sesuai dengan KKM yang ditetapkan). Dalam hal ini belum terdapat peningkatan prosentase ketuntasan belajar siswa.

Jika dilihat dari kategorinya, dapat disampaikan bahwa siswa yang mencapai kategori istimewa sebanyak 2 siswa (20\%); siswa yang mencapai kategori sangat baik sebanyak 2 siswa (20\%); sSiswa yang mencapai kategori baik sebanyak 4 siswa (40\%); siswa yang mencapai kategori cukup sebanyak 0 siswa $(0 \%)$, dan siswa yang mencapai kategori kurang sebanyak 2 siswa (20\%). Dengan demikian, maka modus berada pada nilai “baik" sebanyak 4 siswa (40\%), nilai rata-rata kelas sebesar 82 .

Refleksi dari pelaksanaan tahap pra siklus adalah tingkat ketuntasan belajar siswa belum dapat meningkat, tingkat keaktifan siswa justru turun. Hal ini dimungkinkan siswa belum percaya diri untuk menyampaikan ide dan gagasannya, dan nilai rata-rata siswa sudah meningkat. Hal ini membuktikan bahwa walaupun masih ada siswa yang belum meningkat prestasi belajarnya, namun ada juga siswa yang sudah mengalami peningkatan. Berdasarkan kondisi yang terjadi pada siklus I, maka dipandang perlu untuk melaksanakan siklus II dengan meminimalkan kekurangan pada siklus I.

\section{Siklus II}

Hasil menunjukkan bahwa 10 siswa dari 10 siswa (100\%) dapat mencapai ketuntasan. Hal ini menunjukkan hasil yang sangat signifikan. 
Jika dilihat dari kategorinya, dapat disampaikan sebagai berikut: siswa yang mencapai kategori istimewa sebanyak 4 siswa (40\%), siswa yang mencapai kategori sangat baik sebanyak 2 siswa (20\%), siswa yang mencapai kategori baik sebanyak 3 siswa (30\%), siswa yang mencapai kategori cukup sebanyak 1 siswa $(10 \%)$, siswa yang mencapai kategori kurang sebanyak 0 siswa (0\%).

Dengan demikian, maka modus berada pada nilai 100 sebanyak 4 siswa (40\%) nilai rata-rata kelas sebesar 89.

Refleksi dari pelaksanaan tahap pra siklus adalah: siswa sudah mampu konsentrasi dalam belajar, terlibat aktif dalam proses pembelajaran yang dibuktikan dengan meningkatnya tingkat ketuntasan belajar, nilai rata-rata kelas, modus, dan tingkat keaktifan. Guru sudah tidak lagi berlaku sebagai single actor, tetapi sudah berperan sebagai fasilitator. Berdasarkan kondisi yang terjadi pada siklus II, maka penelitian untuk materi ini sudah cukup dan berhenti pada siklus II.

\section{KESIMPULAN}

Tingkat ketuntasan pada siklus I mencapai 7 siswa (70\%) dan pada siklus II juga mencapai 10 siswa (100\%) . Sedangkan untuk nilai rata-rata kelas, pada siklus I mencapai 82 dan nilai rata-rata kelas pada siklus II naik menjadi 89 . Berdasarkan hal tersebut di atas maka dapat disimpulkan bahwa terjadi peningkatan prestasi belajar mata pelajaran IPA melalui model pembelajaran bamboo dancing bagi siswa kelas VI di SDN 1 Watuagung Kecamatan Watulimo Kabupaten Trenggalek pada semester I tahun pelajaran 2016/2017.

\section{SARAN}

Saran-saran yang dapat disampaikan sesuai dengan hasil penelitian ini adalah sebagai berikut. Sesuai dengan hasil, penelitian membuktikan bahwa model pembelajaran inovatif dapat meningkatkan prestasi belajar siswa. Oleh karena itu diharapkan agar guru dapat menguasai berbagai macam model pembelajaran inovatif, bukan hanya bamboo dancing saja, sehingga siswa tidak merasa bosan.

\section{DAFTAR RUJUKAN}

Arikunto, Suharsimi. 2009. Prosedur Penelitian Suatu Pendekatan Praktek. Jakarta: Rineka Cipta

Fathurrohman, Muhammad. 2015. Model Pembelajaran. Yogyakarta:Teras Huda, Miftahul. 2013. Cooperative Learning Metode, Teknik, Struktur, dan Model Penerapan. Yogyakarta: Pustaka Belajar.

Kemendikbud. 2012. Modul Pengembangan Materi BidangStudy. Malang: UM

Shoimin, Aris. 2014. 68 Model Pembelajaran Inovatif dalam Kurikulum 2013. Yogyakarta: Ar-Ruzz Media.

Susilo. 2007. Penelitian Tindakan Kelas. Pustaka Book Publisher.

Sutikno, Hobri. 2007. Penelitian Tindakan Kelas. Banduyng:Alfabeta 